\title{
Assessing impact of ICT intercultural work
}

Article · July 2014

DOI: 10.4018/ijicte.2014070101

4 authors, including:

$$
\text { Angela Rickard }
$$

National University of Ireland, Maynooth

5 PUBLICATIONS 33 CITATIONS

SEE PROFILE
Roger Austin

Ulster University

46 PUBLICATIONS 223 CITATIONS

SEE PROFILE

Some of the authors of this publication are also working on these related projects:

Centre for Higher Ed Research View project

Exploring Learning with technology View project 


\title{
Assessing Impact of ICT Intercultural Work
}

\author{
Angela Rickard, Maynooth University, Maynooth, Ireland \\ Alma R.C. Grace, Maynooth University, Maynooth, Ireland \\ Roger S.P. Austin, University of Ulster, Coleraine, Northern Ireland \\ Jane M. Smyth, University of Ulster, Coleraine, Northern Ireland
}

\begin{abstract}
This article reports on a school-based ICT initiative, called Dissolving Boundaries (DB) which links primary, (students aged 5-11), post-primary (students aged 12-18) and special schools (students aged 5-18) in partnerships across the border between Northern Ireland and the Republic of Ireland. The aim of the research was to investigate if participation in $D B$ was associated with an increased awareness and understanding of life on the other side of the border. The ICT skills of students were also probed. Two cohorts of students were used in the study, one which had taken part in the Dissolving Boundaries program during an academic year and another cohort of similar age in the same schools, which had not taken part. Findings suggest that participation in the program contributed to students' $k$ nowledge and awareness in general of the other jurisdiction. In terms of collaborative work, a large majority of $D B$ students agreed that they could learn something new from working with another school. Participating students in the DB program showed much higher competence in those ICT skills associated with communication and collaboration than their non-participant peers.
\end{abstract}

Keywords: $\quad$ Collaboration, Contact Hypothesis, Cultural awareness, ICT, School

\section{INTRODUCTION}

Academic debate about the importance of schools in promoting the values of respect, tolerance and openness to cultural diversity is not new, but the issue has attracted increased attention in recent years (Leavy, 2005; Waldron \& Pike, 2007; Devine, Kenny \& Macneela, 2008; Donnelly, 2010; Hasler \& Amichai-Hamburger, 2013). The dangers of negative stereotyping and inertia that hinder the development of such values are documented in educational literature (Hasler \& Amichai-Hamburger, 2013; Donnelly \& Hughes, 2006; Ligorio \& Van der Meijdent, 2008) and it is clear that positive attitudes, particularly in contexts where tensions and mutual distrust have prevailed, need to be modelled, nurtured and celebrated in order to be sustained throughout a person's life (Brown, 2000; Connolly, Smith \& Kelly, 2002;

DOI: $10.4018 /$ ijicte. 2014070101 
Montgomery \& McGlynn, 2009). Educational policies and curricular aims designed to challenge and discourage racism, xenophobia and all other forms of bias against others are welcome because they articulate the appropriate values of a democratic and civilised society. However, such policies are only liable to result in lasting attitudinal change when practical models are implemented in schools and elsewhere that will enable culturally diverse groups to come into contact with each other in meaningful ways and that tap into children's centres of interest and motivation. (Niens \& Chastenay, 2008; Bonnell et al., 2010)

Changes to the political, social and demographic landscapes of both the Republic of Ireland (RoI) and Northern Ireland (NI) in recent years, coupled with social tensions that appear more salient during times of economic hardship (such as those experienced currently in what is referred to as post-Celtic Tiger Ireland, the period after the economic boom of the 1980s and 1990s) make it imperative that schools model good practice in relation to values of respect, open-mindedness and cultural diversity (Devine et al., 2008; Donnelly, 2010). With this also comes a need for teachers to engage with pedagogies that will contribute to developing positive dispositions among young people. As Connolly et al. (2009) note, awareness among children of their own and others' ethnic identities starts to emerge at a very early age, even in a society where the markers of ethnic difference are not obvious. Yet the still prevalent educational segregation that divides school-goers along religious lines in both RoI and NI (Donnelly \& Hughes, 2006) results in continued social, geographic and symbolic divisions between young people of different cultural and religious backgrounds on the island of Ireland (de Burca \& Hayward, 2012). The limited opportunities for cross-border contacts among young people would likely exacerbate this problem.

\section{THE DISSOLVING BOUNDARIES PROGRAM}

The Dissolving Boundaries through Technology in Education program (DB) (www.dissolvingboundaries.org) was established in 1999 in the aftermath of the signing of the Good Friday/ Belfast Agreement. This political settlement, involving the British and Irish governments and politicians in Northern Ireland was designed to bring about the end of violent conflict in Northern Ireland that had prevailed for three decades. That conflict had resulted in the loss of life of over 3,500 people during that time (Archick, 2013). Dissolving Boundaries is a cross-border school-based exchange program that embeds the use of technology in classrooms with a view to promoting intercultural understanding and awareness among the participating students. The school-based projects undertaken by teachers are conducted with whole class groups over a full academic year. The technology used for this work is combined with support for the opportunity to conduct a face-to-face meeting to further the development of positive relationships between the linked classes.

Currently comprising over 200 school based-projects and having reached as many as 40,000 students since 1999, Dissolving Boundaries is the largest and longest-running technology-based, school-exchange program currently in place on the island of Ireland. It involves schools from primary and post-primary education and from special schools (which include both age cohorts).

Schools are matched by the program team and teachers are brought together for a day and a half-long planning conference held at the start of the school year. Through facilitated discussions at the planning conference, teachers identify the curricular content that will be of equal relevance to both classes and produce a learning agreement. Mindful of the importance of group-togroup contact and of recognizing the value of creating a parity of status between students, the Dissolving Boundaries team links children of roughly the same age and ability. Throughout the year teachers and students in the partnership 
maintain contact using a customised iteration of the open source learning environment Moodle and real-time Internet-based video links. A specially created profile template in Moodle is used for students to introduce themselves. The information input from these profiles can be transferred into a database for later work with numeracy. Moodle forums are used for message exchange, Moodle wikis are used for joint curricular work and schools can also make use of blogs for classroom news or Podcasting and chat facilities. Elluminate is currently the videoconferencing tool available to schools.

\section{CONTEXT}

A central aim of the Dissolving Boundaries program is the promotion of cultural awareness through the purposeful use of technology in the curriculum. The program is underpinned by a broad understanding ofAllport's (1954) contact hypothesis $(\mathrm{CH})$, a concept derived from midtwentieth century social psychology that offers insights into the conditions that are needed for intergroup contact to result in more balanced and informed attitudes among previously divided groups and individuals (Trew, 1989; Pettigrew, 1998; Brown, 2000).

The term "contact hypothesis" was introduced and developed by Williams (1947) and Allport (1954) to understand inter-group relationships in post-war US society. It specified "the critical situational conditions for intergroup contact to reduce prejudice" (Pettigrew, 1998, 66). Connolly defines the contact hypothesis as maintaining that "contact between members of different racial and/or ethnic groups will result in a reduction of prejudice between these groups and an increase in positive and tolerant attitudes" (Connolly, 2000, 169). CH has been used widely in the context of intergroup, cooperative initiatives in Northern Ireland (Trew, 1989; Montgomery \& McGlynn, 2009) and internationally (Pettigrew, 1998; Niens \& Chastenay, 2008; Hoter, Shonfeld \& Ganayem, 2009). Its staying power has been attributed to the simplicity of the idea and the resonance it has for educationalists who bring groups together with a view to creating greater cross-community harmony and understanding (Brown, 2000).

Critics of the hypothesis, cited by Connolly (2000), have argued that it "appears to restrict the nature and causes of racism and ethnic divisions to individual ignorance and misunderstanding" (ibid. 170) and ignores the institutional and state level structures that may reinforce prejudice and ethnic divisions, thereby exonerating the institutional processes that contribute to sustaining divisions. Nonetheless, Connolly argued that the hypothesis continues to offer useful insights for a micro-level analysis of interpersonal development of cultural awareness as part of a "multilayered approach" (ibid., 188) where individual interpersonal and intergroup contacts work in tandem with broader processes aimed at reducing prejudice; he cited Northern Ireland as a case in point, "where broader political negotiations and accommodations are seen as a vital but not sole focus for addressing ethnic conflict" (Connolly, 2000, 171).

Amichai-Hamburger \& McKenna (2006) reconsidered the $\mathrm{CH}$ and pointed out the practical difficulties in achieving positive and beneficial results "under traditional circumstances." (828). They noted the absence of references to the Internet in the literature on the contact hypothesis. More recent discussion of the affordances of the Internet to overcome some of the practical impediments to realising the potential of group contact are of particular relevance for the Dissolving Boundaries program (Austin, 2011; Hasler \& Amichai-Hamburger, 2013; Xie, Miller \& Allison, 2013; and Kampf, 2011).

The conditions of the $\mathrm{CH}$, such as sustained cooperative contact between those of equal status have helped to shape the design of the DB program. One important element is support from school principals. Another is a recognition that young people need to have the means to interact socially as well as working on aspects of the curriculum.

O’Dowd \& McCall (2008) suggested that cross-border interaction has a role to play in reconciliation within Northern Ireland in that 
for unionist groups (those who favour strong links with the rest of the United Kingdom) it provides a welcome escape from the relentless, conflictual interaction with republicans and nationalists in the North. (The latter two groups have traditionally favoured a reunification of the two parts of Ireland.) For nationalists, cross-border co-operation illustrates the need to reduce ignorance, fear and prejudice. McCall \& O'Dowd (2008) also emphasise the importance of sustainability in cross-border partnerships.

\section{RESEARCH QUESTIONS}

Research and evaluation on the Dissolving Boundaries program has been conducted on different aspects of the use of ICT since 2003. Some of this research has drawn on teachers' views to suggest that taking part has had an effect on students' perception of others (Austin, 2006), a finding supported by two external evaluations (Bonnell, etal. 2011; Education and Training Inspectorate Joint Evaluation Report, 2012). The current study was developed and implemented in 2012 to probe whether it could be shown that Dissolving Boundaries was having an impact on students' cultural awareness and their openness to diversity. We also wanted to examine whether there were differences in attitude between students who had taken part in the Dissolving Boundaries program compared to similar students in the same schools who had not participated.

\section{METHODOLOGY}

This study is principally a descriptive review of data gathered from children in schools that had taken part in the Dissolving Boundaries program compared to data from children in matched classes in the same schools who had not taken part. Data were gathered a year after the students had completed the program.

\section{PARTICIPANTS}

For this survey we identified schools that had at least two classes at the same level in the previous year, one that had participated in the program and one that had not. Our aim in this research was to compare the attitudes of former participants one year after their participation in the program and to the attitudes of sameschool peers who did not participate in it. By looking at the impact of the program a year after students had participated in it, we hoped to address one of the criticisms of exchange projects - particularly those that aim to reduce prejudice - namely that, very often, the impact is short-lived (Trew, 1986; Connolly, 2000; Gallagher, 2008).

\section{INSTRUMENTS}

In order to explore the putative differences between the two cohorts, we developed and administered a 5 section questionnaire containing 43 questions to assess students' knowledge and awareness of a number of general cross-cultural, educational and technology-related themes.

Our survey was designed and piloted in the Spring of 2012. We used a quantitative approach, based on an online questionnaire to collect the data. The questions were designed to be age appropriate and were mostly closed, tick box in style to enable students to work through them with ease. It was administered under the supervision of teachers in the schools. Questions were designed to explore perceptions of similarity and difference in a number of areas, such as hobbies, knowledge of the other side of the border and experience of crossing the border. A small number of questions were open to allow for explanatory comments from students. The questionnaire was piloted in two schools (one on each side of the border) prior to a final version being issued to the selected schools. 
Table 1. The breakdown of school types which responded in Northern Ireland (NI)

\begin{tabular}{|l|l|l|l|}
\hline & Primary & Post-Primary & Overall \\
\hline $\begin{array}{l}\text { Maintained schools } \\
\text { (mainly Catholic) }\end{array}$ & 4 & 1 & 5 \\
\hline $\begin{array}{l}\text { Controlled schools } \\
\text { (mainly Protestant) }\end{array}$ & 4 & 2 & 6 \\
\hline $\begin{array}{l}\text { Integrated schools } \\
\text { (mixed religion) }\end{array}$ & 1 & 1 \\
\hline Special schools & & 1 & 1 \\
\hline Total & $\mathbf{9}$ & $\mathbf{4}$ & $\mathbf{1 3}$ \\
\hline
\end{tabular}

Table 2. The breakdown of school types which responded in the Republic of Ireland (RoI)

\begin{tabular}{|l|l|l|}
\hline Primary & Post-Primary & Total \\
\hline 5 & 4 & 9 \\
\hline
\end{tabular}

\section{PROCEDURES}

We wanted to reach a large enough number in the student sample that would also include as far as possible the full range of school types and student age groups that had taken part in the program. All Dissolving Boundaries schools in Northern Ireland are either in the Controlled, Maintained or Integrated sectors and are all state funded. The difference between sectors is that the employing authorities are different but more importantly in this context, the intake of the schools is very different. Controlled schools are most likely to have an overwhelmingly 'Protestant' intake while in Maintained schools, most students would be 'Catholic' In the case of the very small Integrated sector, schools are set up to educate children of all denominations together (see Table 1).

Schools were identified that had sufficient enrolment numbers to have two class groups in the same age category. Two classes in each school participating in the research were surveyed, one class that had taken part in the Dissolving Boundaries program in the previous year and a second, to act as a control group, that had not been involved. Both were surveyed using the same questionnaire.

Because of the class comparison requirement, the smaller primary schools participating in the program were not surveyed on this occasion.

A total of 30 schools corresponding to the profile we were looking for were approached, 15 from each side of the border. Responses were received from 22 schools in total, 13 from Northern Ireland and 9 from the Republic of Ireland (see Table 2).

In all 611 students responded to the survey:

- $\quad$ Northern Ireland: 380 students (62\%)

- $\quad$ Republic of Ireland: 231 students (38\%).

\section{DATA ANALYSIS AND DISCUSSION}

From the total number of students who responded, $65 \%$ had taken part in Dissolving Boundaries $(n=394)$ and $35 \%$ had not $(n=209)$ (data missing from 8 respondents). Of the respondents who said they had taken part in the program, $60 \%$ 
Figure 1. Percentage of students in each age group

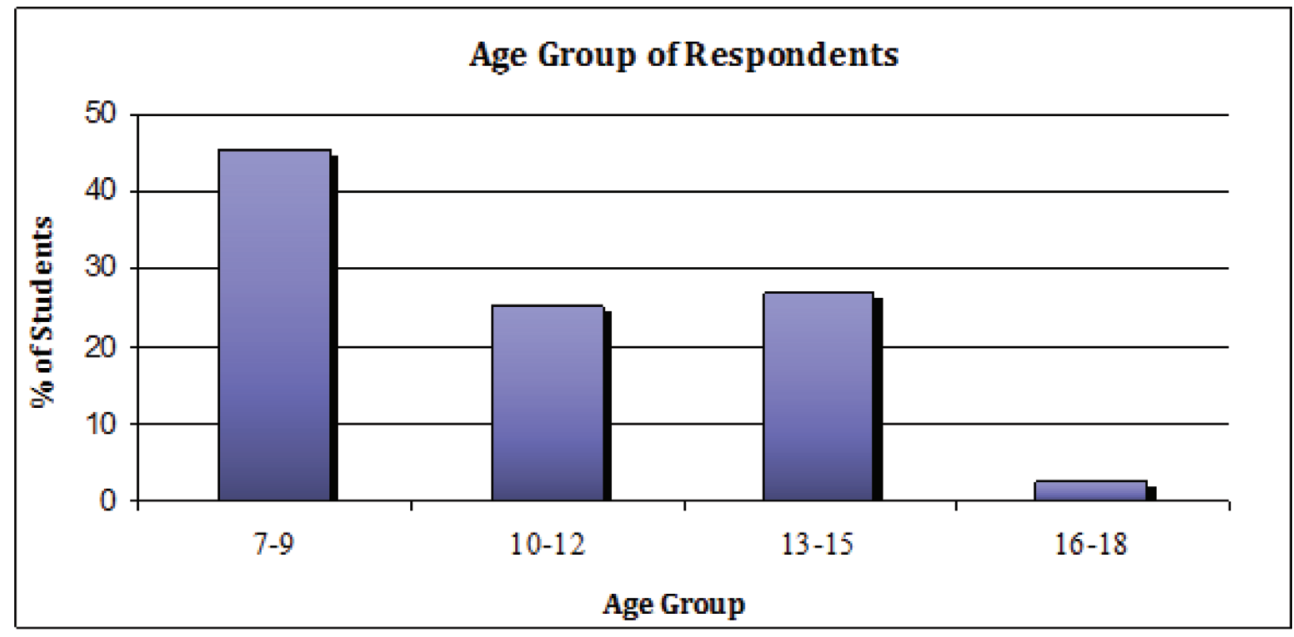

were from Northern Ireland and $40 \%$ came from the Republic of Ireland. The gender of students who responded was: $51 \%$ boys and $49 \%$ girls. The age range of the students who responded is represented in Figure 1:

\section{RELIGIOUS AFFILIATION}

The issue of identity and religion for young people in an Irish context is complex. (Muldoon, McLaughlin \& Trew, 2007). Within Northern Ireland in particular, religious views are sometimes perceived to coincide with political allegiance. For example, Catholics in Northern Ireland would be assumed to be more likely than Protestants to favour links across the border with the Republic of Ireland (McCall \& O'Dowd, 2008). The latest census data shows that in Northern Ireland $45 \%$ of the population is Catholic or brought up Catholic and $48 \%$ is Protestant or brought up Protestant. In the Republic of Ireland $84 \%$ of the population state that they are Catholic, with $4 \%$ stating that they are Protestant.

Of the total number of respondents in our survey, 22\% described themselves as Protestants, $59 \%$ as Catholics, with the remainder $(19 \%)$ made up of those who chose one of the categories "Other" or "No religion" or "Don't know." (A total of 7 students from the Republic of Ireland described themselves as Protestant, representing $1.1 \%$ of the total population surveyed). Because of the insignificant number of Protestant students in the Republic of Ireland in this survey, for the purposes of discussion of religious affiliation, when we refer to Protestant students, we are referring mainly to students who live in Northern Ireland.

Together with the gathering of factual information in the survey, further questions were designed to explore perceptions of similarity and difference in a number of areas, such as students' perceptions of the other side of the border, what sports were played, what hobbies children enjoyed, what religion was practiced.

We asked those who had participated if they knew the religion of their partner students; some students felt they knew the religion of the students in their partner school, but the largest group (36\%) didn't know what religion they belonged to and $26 \%$ of students thought their partner students came from mixed religion schools. This could indicate that the religion of the partner students was of no great relevance or interest, or that they were reluctant to say. It could also indicate that students have poor 
Figure 2. Religious affiliations of respondents

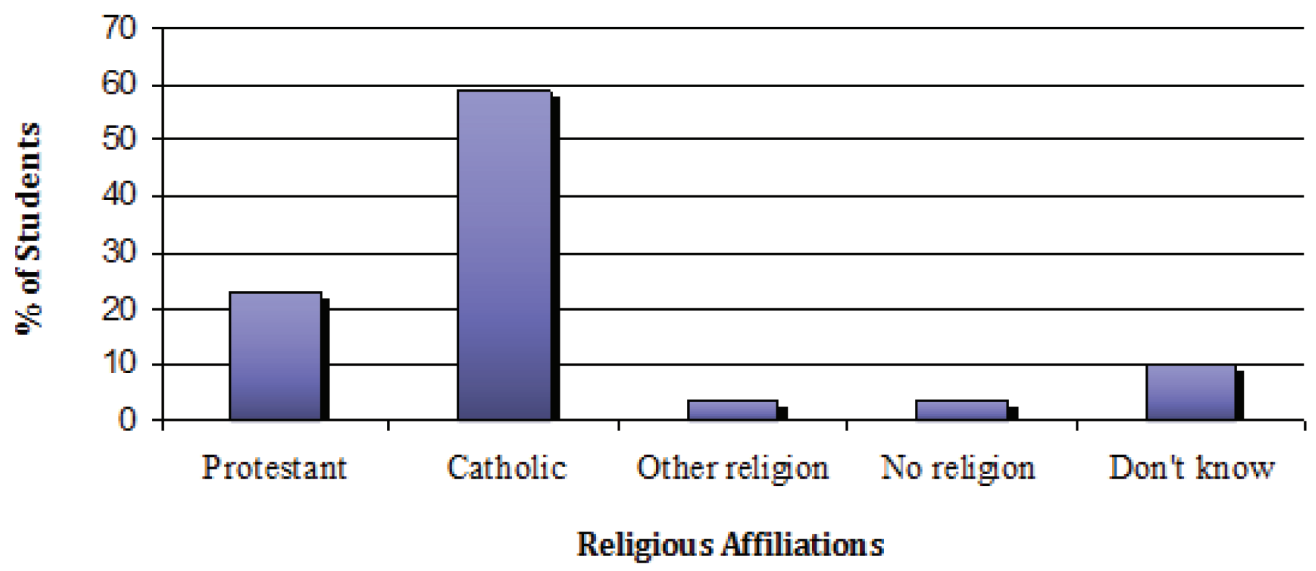

understanding of school systems on the other side of the border.

The idea of religion being an adult construct and the fact that children don't always know which religion they belong to is raised by McGlynn, who analyses ethnicity and political and religious identity in her study of integrated Zemblyas \& McGlynn, 2009). Waldron \& Pike (2007), in their analysis of children's writing in schools in the Republic of Ireland, noted that there was little mention of religion, which they interpreted as an indication of growing pluralism. education in Northern Ireland. (Bekerman,

Figure 3. Respondents' perceptions of the religious affiliations of the students in their partner school

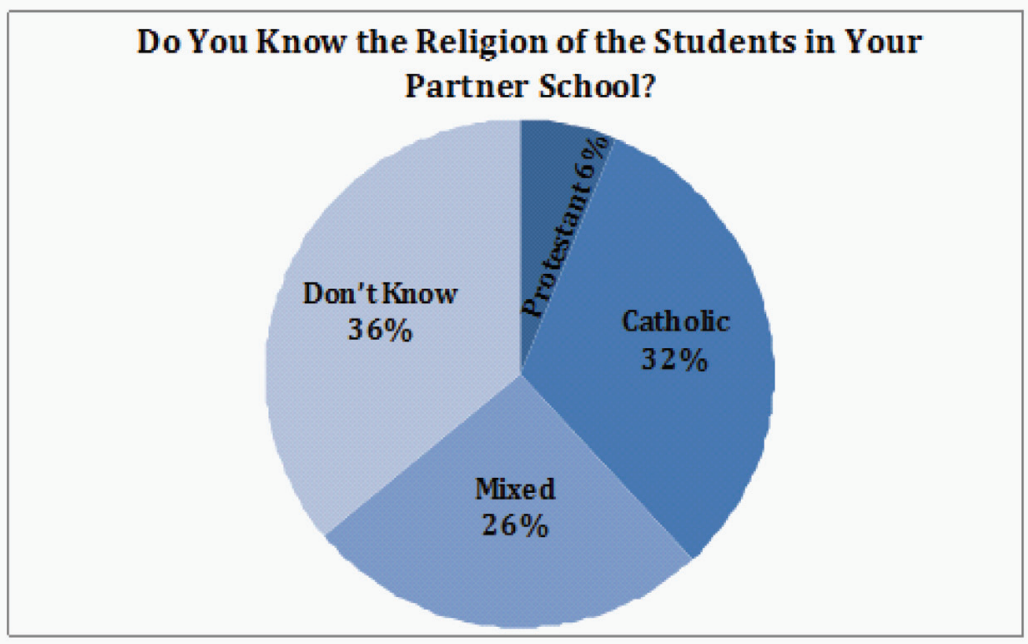


Figure 4. Frequency of border crossings of respondents

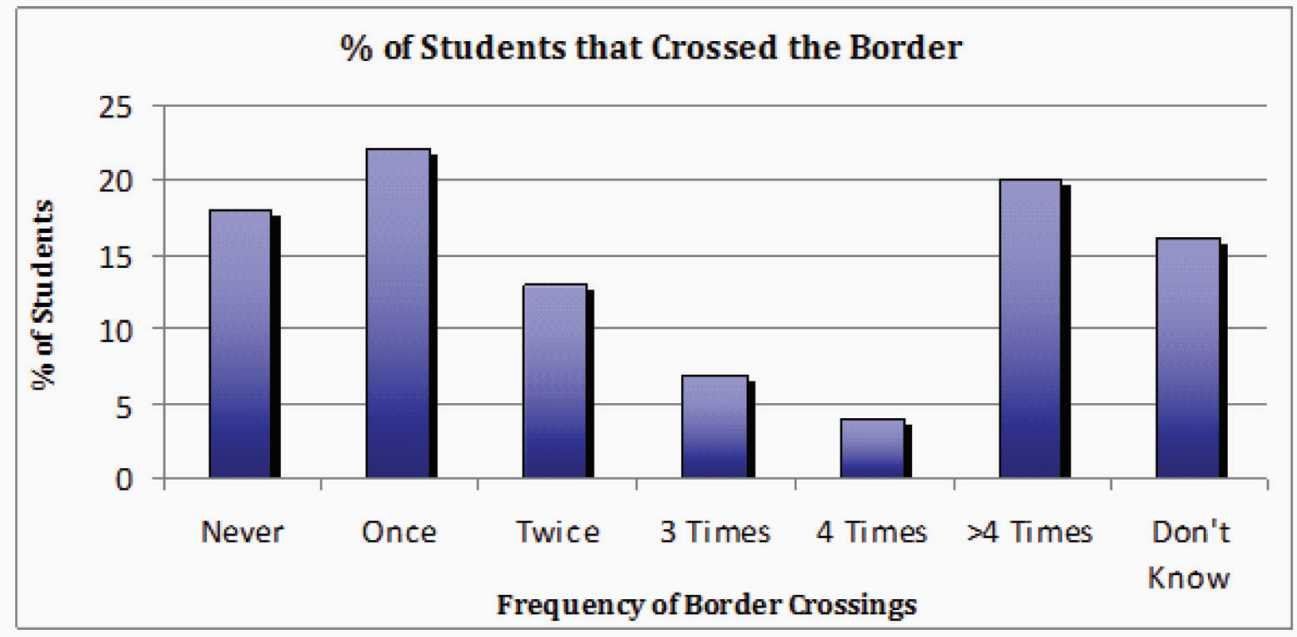

\section{CROSSING THE BORDER}

Students were asked if they had crossed the border and if so, how often. As seen in Figure 4 , a total of $18 \%$ of students had never crossed the border, while a total of $20 \%$ had crossed it more than 4 times in the previous 12 months.

As can be seen in Table 3, 15\% of the DB participants had never crossed the border while $23 \%$ of those who had not taken part had never done so. $70 \%$ of the DB participants had crossed the border while $58 \%$ of those who had not taken part had crossed the border.

Of those who had crossed the border more than four times, $62 \%$ had taken part in DB, while $38 \%$ had not. The reasons for crossing the border were quite varied:

Table 4 shows higher figures in all categories from students involved in DB, with the biggest discrepancy in numbers coming from the School trip category, where $87 \%$ of those who took part in DB had crossed the border while only $13 \%$ of those who did not participate in DB had crossed the border for a school trip. Of the most frequent visitors across the border (more than 4 times during this year), 7\% came from the Protestant group and $78 \%$ came from the Catholic group.

The data also revealed a greater proportion of students traveling from north to south than the other way around. For example $12 \%$ of all Northern students claimed to have never crossed the border, while $27 \%$ of all RoI students never crossed the border. Of those who said they crossed the border to visit family, $71 \%$ came from Northern Ireland, with $29 \%$ from the Republic of Ireland. Only shopping broke this trend, with $62 \%$ of Southern students citing this as a reason for crossing the border.

Table 3. Comparison of border crossings between $D B$ and non-DB students

\begin{tabular}{|l|l|l|l|}
\hline & \% Never Crossed Border & \% Have Crossed Border & \% Don't Know \\
\hline DB students & 15 & 70 & 15 \\
\hline Non-DB students & 23 & 58 & 19 \\
\hline
\end{tabular}


Table 4. Reasons for crossing the border

\begin{tabular}{|l|l|l|l|l|l|}
\hline Reason for Crossing Border & Visit Family & Visit Friends & School Trip & Holiday & Shopping \\
\hline DB students & $60 \%$ & $64 \%$ & $87 \%$ & $65 \%$ & $61 \%$ \\
\hline Non-DB students & $40 \%$ & $36 \%$ & $13 \%$ & $35 \%$ & $39 \%$ \\
\hline Northern students & $70 \%$ & $70 \%$ & $66.5 \%$ & $83 \%$ & $38 \%$ \\
\hline Southern students & $30 \%$ & $30 \%$ & $33.5 \%$ & $17 \%$ & $62 \%$ \\
\hline
\end{tabular}

\section{HOW WELL DO YOU THINK YOU KNOW THE OTHER SIDE OF THE BORDER?}

Our survey explored the extent of students' knowledge of "the other side of the border" and from Table 5 it is clear that participation in the program contributes to their knowledge and awareness in general of the other jurisdiction.

Of those who said they knew a lot about the other side of the border, $77 \%$ were from the group who took part in DB. Also, of those who claimed to know a lot about the other side of the border, $21 \%$ described themselves as Protestant, $65 \%$ as Catholic. In the general population surveyed, students from Northern Ireland knew as much or as little about the other side of the border as those from the Republic of Ireland. When asked more specific geographical questions, the majority of students answered correctly, regardless of age, location, or whether or not they had taken part in DB.

Asked if they thought students on the other side of the border were different from themselves, $50 \%$ thought they were different.
This figure was similar for both $\mathrm{DB}$ and non-DB students and also for students north and south. Looked at from the point of view of the students' religious affiliation, $58 \%$ of Protestants thought that students on the other side of the border were different from themselves, $15 \%$ thought there was no difference and $27 \%$ didn't know. $48 \%$ of Catholics thought they were different, $34 \%$ thought there was no difference and $19 \%$ didn't know (see Figure 5).

These figures are corroborated by responses to the question "What words come to mind when you think about the other side of the border?" as many students, particularly participants in the DB program, mentioned the word "different." We suggest that this reflects a greater awareness amongst DB students who are more informed about their peers across the border. This awareness makes it clear that contact does not mean that everyone thinks "we are the same." Noteworthy is the fact that more Protestant students felt that difference. This might possibly be explained by the fact that Catholic students in Northern Ireland feel more of an affinity with

Table 5. Knowledge of the other side of the border

\begin{tabular}{|l|l|l|l|}
\hline $\begin{array}{l}\text { How well do you think you know the other side } \\
\text { of the border? }\end{array}$ & I know a lot & I know some things & $\begin{array}{l}\text { I know a Imost } \\
\text { nothing }\end{array}$ \\
\hline DB students & $12 \%$ & $67 \%$ & $21 \%$ \\
\hline Non-DB students & $7 \%$ & $51 \%$ & $42 \%$ \\
\hline Northern students & $11 \%$ & $60 \%$ & $29 \%$ \\
\hline Southern students & $8 \%$ & $65 \%$ & $27 \%$ \\
\hline Protestant students & $9 \%$ & $53 \%$ & $38 \%$ \\
\hline Catholic students & $11 \%$ & $67 \%$ & $22 \%$ \\
\hline
\end{tabular}


Figure 5. Comparison of responses between Protestant and Catholic students

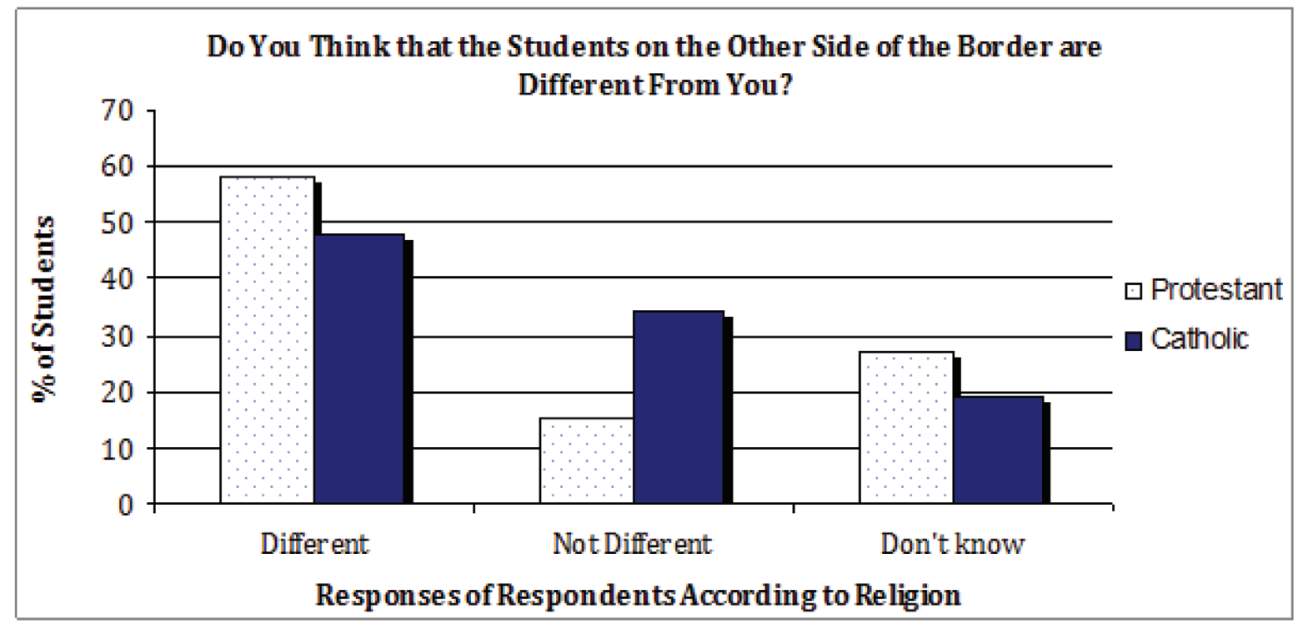

the Republic of Ireland, which, as stated above, is predominantly a Catholic country.

Students were asked "What words come to mind when you think about the other side of the border?" The three most frequently used words were: "Fun," "Nice," and "Accent." Indeed, the majority of words that came to mind for students were very positive and were used by both Northern and Southern students. Responses with a positive tone were less frequently reported from those who did not participate. Place names and the word "euro", (the European currency) tended to be the words associated with across the border from those who didn't take part in Dissolving Boundaries.

The words "don't know" or "nothing" came up 22 times from amongst the group who did not participate - possibly an indication of a greater indifference or lack of knowledge among those who did not participate. Some derogatory words were also used amongst this group.

Words referring to "Trouble" or "Violence" all came from RoI students - 15 instances altogether from participating students and 8 from non-participating: this represents $10 \%$ of all RoI respondents while the absence of such comments from students in Northern Ireland is perhaps an indication that among the so called
"Agreement generation" of Northern Ireland these negative connotations are diminishing.

\section{HOBBIES: SPORT, MUSIC AND READING}

The survey revealed that students felt there were differences between them in relation to hobbies of music and reading but interest in sports was largely considered to be similar on each side of the border.

A general question was first asked about students' attitude to sport and, unsurprisingly, a very high number $(92 \%)$ of all students said they liked sport. When asked if they thought that students on the other side of the border played the same sports as themselves, $59 \%$ of all students said yes, 12\% said no, and 29\% didn't know. (This data was similar for DB and non-DB students.) When this data was looked at from a religious affiliation point of view, fewer Protestant students thought those across the border played the same sports as them $(38 \%)$ while $68 \%$ of Catholics thought those across the border played the same sports as themselves, indicating possibly that a general perception of shared tastes and traditions in sports exist among Catholics on each side 
Figure 6. Percentage of students who said they could carry out named computer-based tasks

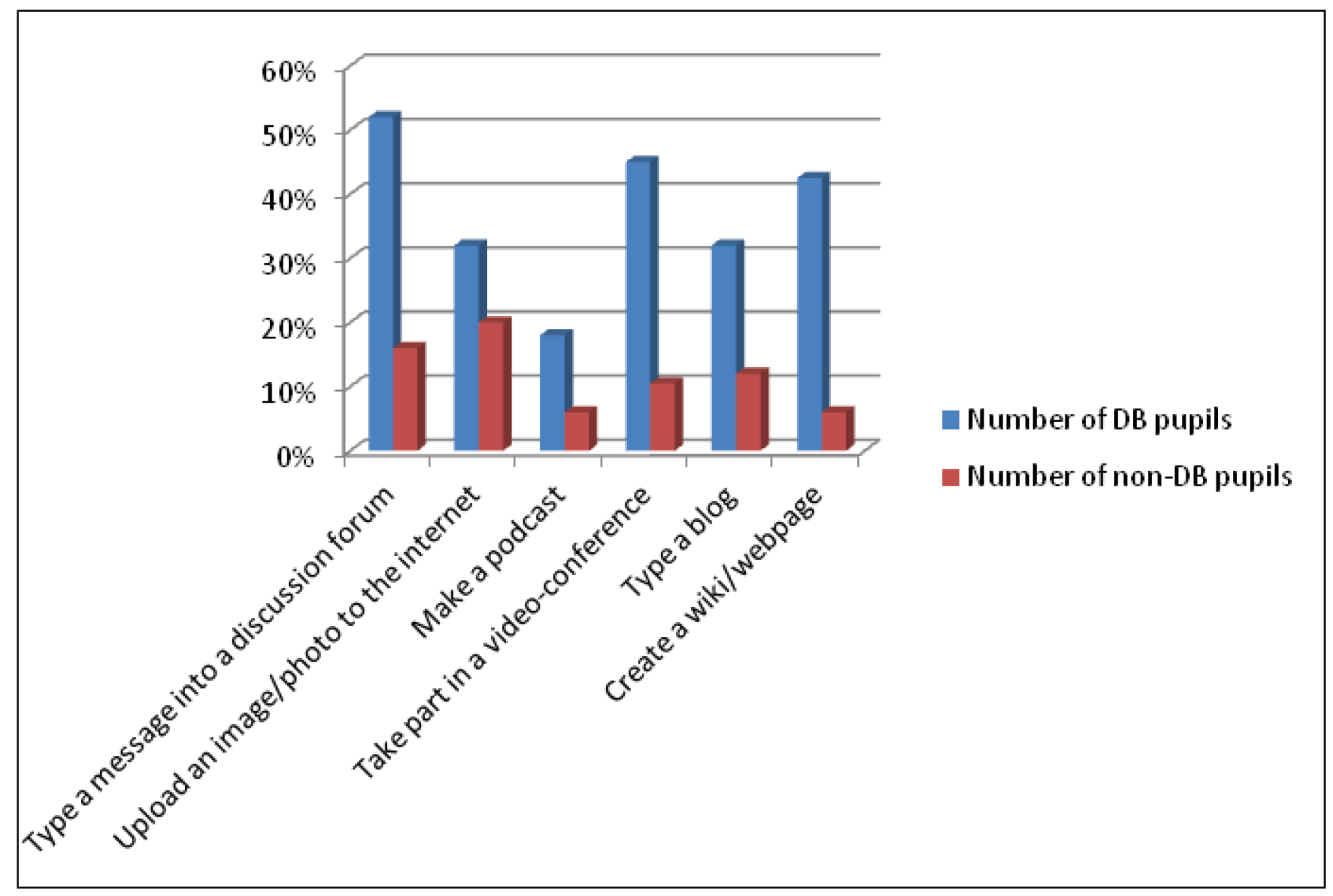

of the border. One reason for this might be the existence of the All-Ireland Gaelic Athletic Association (GAA) which is predominantly a Catholic sporting organisation, from which the Protestant population largely feels excluded.

In relation to music, similarly, when asked the general question if they liked to listen to music $95 \%$ said yes. Fifty percent played a musical instrument, with equal numbers from North and South in this category. In response to the more specific question "What type of music and books do you think students on the other side of the border are interested in?" just $21 \%$ thought that students on the other side of the border read the same type of books and listened to the same type of music as them. This figure was 9\% among Protestant students while 29\% ofCatholic students thought that similar tastes in music and reading prevailed across the border. Forty-one percent of students thought they read different books and listened to different music. Thirty-seven percent didn't know. (Reading as a hobby was popular on both sides of the border with $74 \%$ of all Northern students liking reading and $72 \%$ of all Southern students liking it).

\section{KNOWLEDGE AND EXPERIENCE OF USING TECHNOLOGY}

Dissolving Boundaries has been cited by teachers in earlier research by the program team to be instrumental in developing students' awareness and skills in using technology (Austin, Abbott, Mulkeen \& Metcalfe, 2003). In the current survey, in order to establish firstly the competence of the students in the use of ICT, we asked them what tasks they could perform on the computer. Figure 6 compares the numbers of DB and non-DB students in their ability to carry out various computer-based tasks.

Among the respondents $(\mathrm{N}=567)$ to the question "Have you ever used the Internet to work with students in another school?" $49 \%$ had used the Internet to work with students in another school, $41 \%$ had not, with $10 \%$ 
Figure 7. Percentage of $D B$ and non-DB Students that have used the Internet to work with students in another school

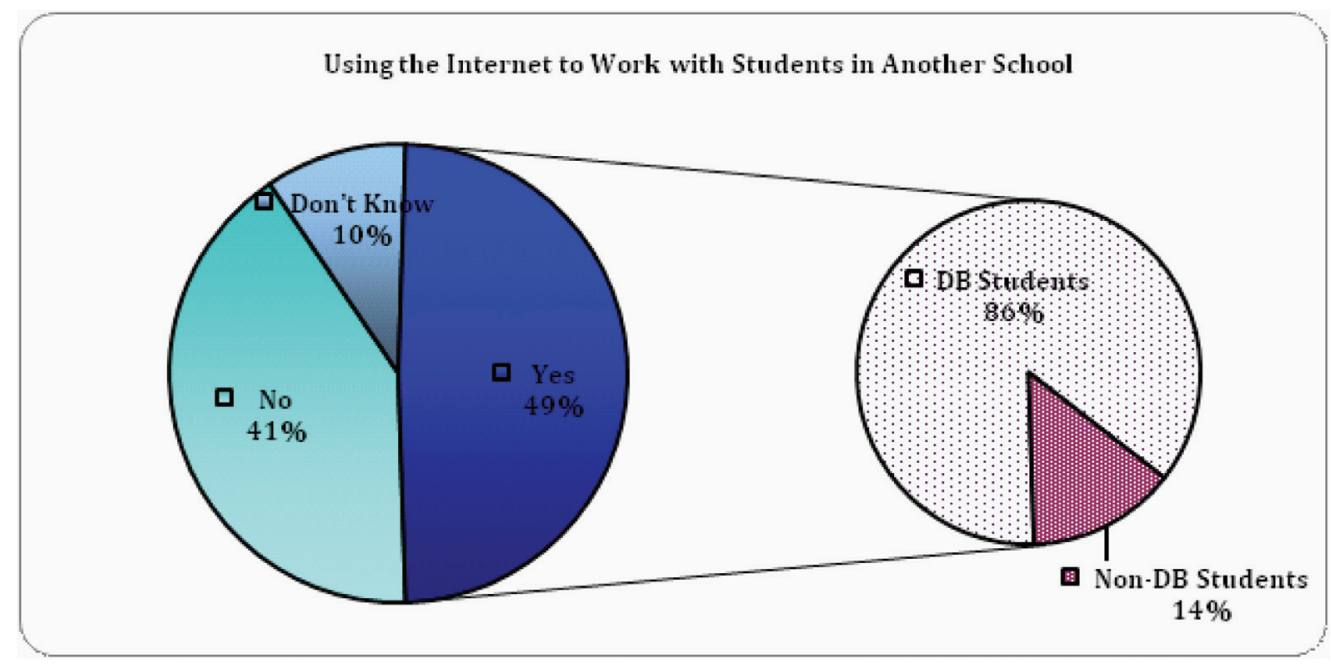

who didn't know. Of the 277 students who responded yes to this question, $86 \%$ of them had participated in DB and 14\% had not. Looking at this data from a north-south perspective, $53 \%$ of Northern Ireland students had used the Internet to work with students from another school, 33\% had not and 14\% didn't know (see
Figure 7). In the Republic of Ireland $42 \%$ of students had worked with another school using the Internet with 53\% saying they hadn't and $5 \%$ didn't know.

Students were asked how they felt about the experience of using the Internet to communicate with another school. Sixty two percent described

Figure 8. Percentage of $D B$ and non- DB Students that rate their experience of using the Internet to work with students in another school as a positive one

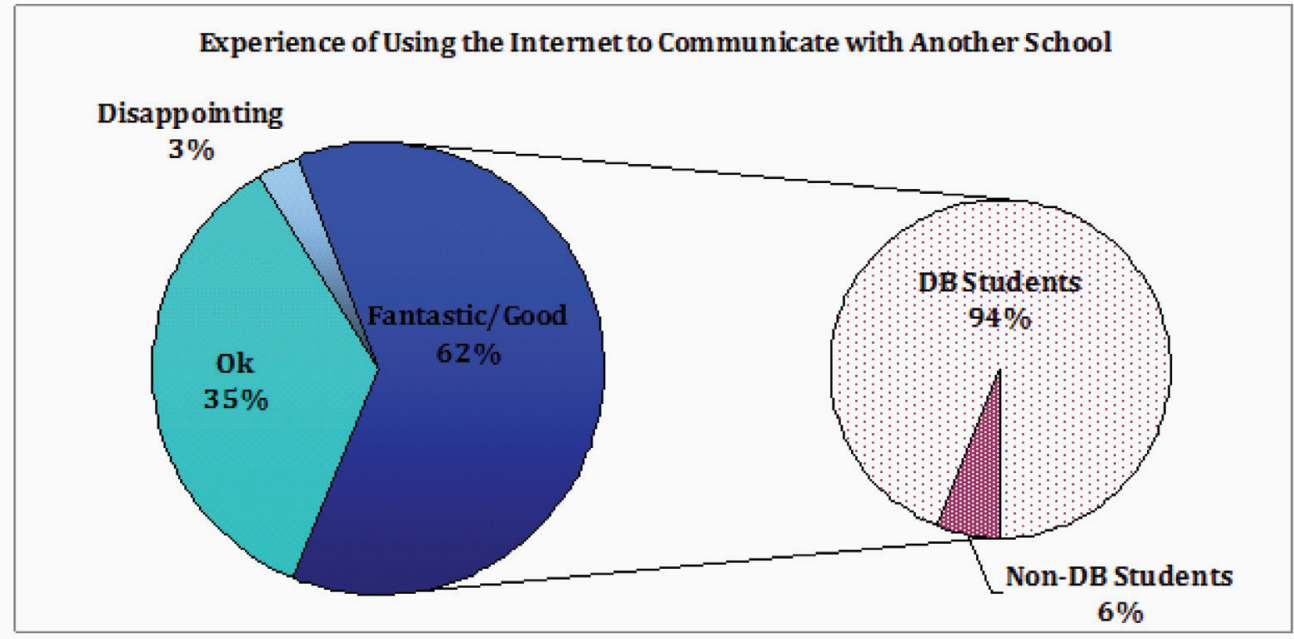

Copyright $(\mathcal{C}$ 2014, IGI Global. Copying or distributing in print or electronic forms without written permission of IGI Global is prohibited. 
Table 6. Sending messages to students in another school

\begin{tabular}{|l|l|l|l|}
\hline $\begin{array}{l}\text { Do you like the idea of sending messages to students in } \\
\text { another school? }\end{array}$ & Yes & No & Don't Know \\
\hline DB students & $87 \%$ & $5 \%$ & $8 \%$ \\
\hline Non-DB students & $64 \%$ & $21 \%$ & $15 \%$ \\
\hline Northern students & $80 \%$ & & \\
\hline Southern students & $78 \%$ & & \\
\hline Protestant students & $74 \%$ & $16 \%$ & $10 \%$ \\
\hline Catholic students & $84 \%$ & $8 \%$ & $8 \%$ \\
\hline
\end{tabular}

it as a fantastic/good experience, $35 \%$ described it as OK, with $3 \%$ considering it a disappointment. Among those who considered this to be a fantastic or good experience, $(\mathrm{N}=170), 94 \%$ were from the group who participated in DB and $6 \%$ from the group who did not participate. Of those who considered working with another school as an "OK" experience, $73 \%$ came from the DB group while $27 \%$ came from the group who did not participate. A total of 9 students felt that the experience of using the Internet to work with another school was disappointing $(3 \%$ of 274 respondents) and these all came from Protestant respondents in Northern Ireland, 6 of whom had taken part in DB (see Figure 8).

Looking at this data again from a northsouth perspective, $60 \%$ of Northern students felt this was a fantastic or good experience and $66 \%$ of students from the Republic felt it was fantastic or good. From a religious perspective, Catholics were considerably more likely $(72 \%)$ than their Protestant counterparts (45\%) to think that communicating with another school using ICT was a fantastic or good experience.

\section{SENDING MESSAGES TO ANOTHER SCHOOL}

The DB program opens opportunities for links to others that might not otherwise exist for students and to create the space for interaction with others in a meaningful context for shared work in groups to occur.
In response to the question "Do you like the idea of sending messages to students in another school?" Table 6 shows that $80 \%$ of all respondents indicated that they liked the idea. Ten percent did not like this idea and 10\% didn't know. From the group who participated in Dissolving Boundaries, the positive response was $87 \%$, with $5 \%$ saying they did not like this idea. From the group who did not participate in $\mathrm{DB}$, the positive response was smaller, $64 \%$, with $21 \%$ saying that they didn't like this idea.

Seventy-four percent of Protestant students said they liked the idea of sending messages to another school, $16 \%$ said no and $10 \%$ didn't know. Eighty-four percent of Catholic students liked the idea, $8 \%$ didn't like the idea and $8 \%$ didn't know. Younger students were more positive about sending messages to another school, with $83 \%$ of the two younger age groups saying they liked this idea. This figure dropped to an average of $60 \%$ in the two older age groups. This positivity amongst younger students is perhaps explained by the less inhibited approach often displayed by young children. This finding suggests that children can avoid "negative attitudes towards others" by engaging with ICT to communicate with these "others." (Connolly et al., 2009)

Figures for north and south in this category are very similar, with $80 \%$ of Northern students and $78 \%$ of Southern students liking the idea of sending messages to students in another school. 
Figure 9. Comparison of responses between $D B$ and non-DB students

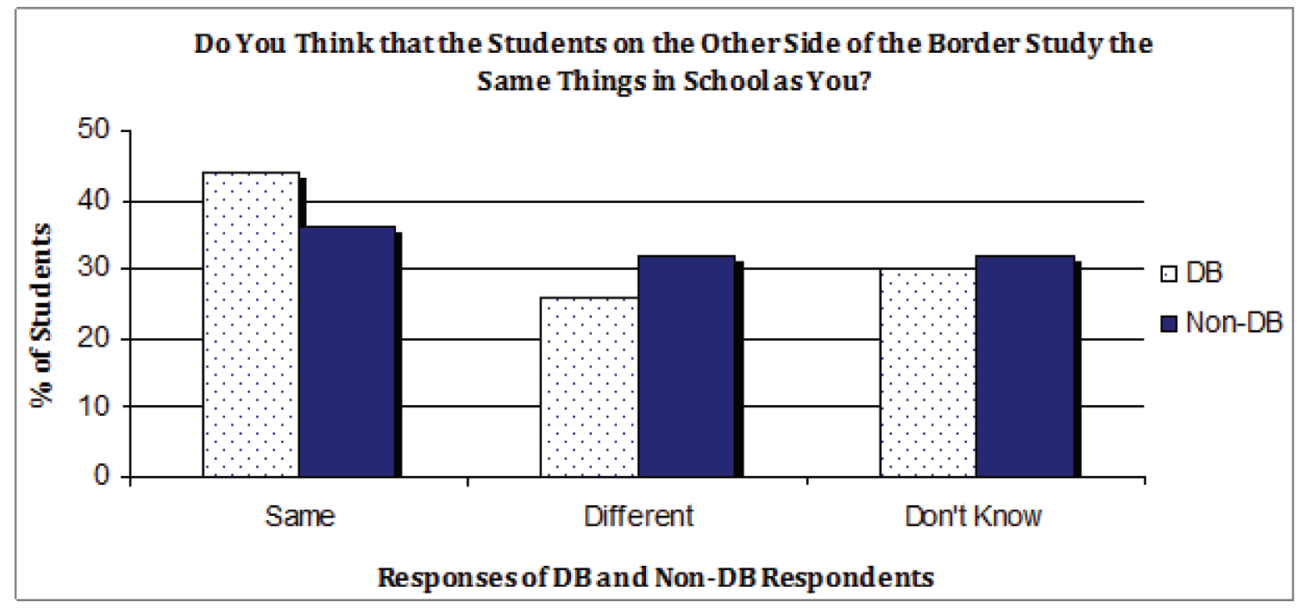

\section{COLLABORATIVE LEARNING}

Ligorio \& Van der Meijdent (2008) outlined the challenges facing teachers working collaboratively in an online environment. DB, recognizing these challenges, puts emphasis on groupwork within the classroom and from class to class. One of the collaborative ICT tools chosen by DB to support social constructivist learning is the wiki. Cress \& Kimmerle (2008) highlight the complexity of this type of work and acknowledge the possible learning outcomes such as the social processes facilitated by a wiki, the cognitive processes of the users, and how both processes influence each other mutually.

LeBaron \& McDonough (2009) in their review of ICT in education also refer to several studies which make the point that ICT holds unprecedented potential for cross-border, intercultural learning, teaching, and curriculum development, which are areas that $\mathrm{DB}$ continue to address for teachers and students in the program.

Asked if they liked working in a group at school, a greater proportion of DB students said yes $(83 \%)$ while $74 \%$ of non-DB students liked this. Of the total group who said yes, $69 \%$ of students belonged to the DB group and 31\% belonged to the non-DB group.
When asked if they thought they could learn anything new from working with another school, the majority of students agreed they could. Of the overall group who agreed with the idea that they could learn from working with another school, $70 \%$ had participated in DB while $30 \%$ had not. Female students were more positive in this regard with $76 \%$ of girls agreeing that they could learn something new from working with another school, while $66 \%$ of boys agreed. Younger students were more likely to agree, with $75 \%$ of those between seven and 12 saying they thought they could learn something new from working with another school, while $53 \%$ of the older age group (13 - 18 year olds) agreed.

When looked at from the religious affiliation, 58\% of Protestants thought they could learn something new from another school, $17 \%$ thought they couldn't and 25\% didn't know. Seventy-nine percent of Catholics thought they could learn something new from another school, $11 \%$ thought they couldn't and $10 \%$ didn't know. 


\section{PERCEPTIONS OF THE CURRICULUM}

When asked if they thought students studied the same things in school on both sides of the border, students had different perceptions. Thirty-two percent of Protestant students thought they all studied the same things, 38\% did not agree and $30 \%$ of these students didn't know. Of the Catholic students surveyed, $47 \%$ thought everyone studied the same things, 25\% didn't agree and $28 \%$ didn't know. Of those who participated in DB, as we can see in Figure 9 44\% thought that students on the other side of the border studied the same things at school as themselves, $26 \%$ thought they learned different things and $30 \%$ didn't know. Of the students who did not participate in $\mathrm{DB}, 36 \%$ thought the students across the border studied the same things at school as they did, $32 \%$ thought they learned different things, and 32\% didn't know. These figures suggest that, regardless of participation in DB, students' understanding of each other's curriculum is limited.

Finally, we asked students if they would want to work with another school on the Internet in the future. Seventy nine percent agreed, 7\% said no and $14 \%$ didn't know. From the total number who responded to this question (274 respondents), 235 had already participated in Dissolving Boundaries (86\%) with only $14 \%$ among those who had not participated. The positive result came from both north and south, with $78 \%$ of NI students saying yes, $82 \%$ of RoI students saying yes. Looking at this data from a religious affiliation viewpoint, a difference emerged $-89 \%$ of Catholic students said they would want to work with another school on the internet again, while $60 \%$ of Protestant students wanted to work with another school again.

\section{CONCLUSION}

The decision to undertake this research is timely given that the cohort in the survey, whether in primary or in second level schools, on either side of the border, have all experienced child- hood in a culturally diverse society unlike that of their parents' and teachers' generation. This is especially relevant for the participants in Northern Ireland who are the first generation of children in over half a century to grow up in a (relatively) peaceful environment (Nolan, 2012), the so-called "Agreement generation" (de Burca \& Hayward, 2012).

This is the first piece of research by DB which has looked at the effect of an intervention program a year after its completion and at the same time to have been able to compare the experiences of children who have participated compared to a group that have not been involved. The size of the data set and the rigorous methodology indicate that we can have some confidence in the findings.

Dissolving Boundaries is an ICT program connecting schools on both sides of the border between Northern Ireland and the Republic of Ireland. While we have not conducted tests of statistical significance, the large differences observed in the current research suggest that participating students' capabilities in using ICT were improved. They also indicate that the participating students' awareness of the affordances of technology for learning and communicating were more developed than among their nonparticipating counterparts. It is unsurprising to find that students who participated in the program were more likely than those who had not to feel confident at performing tasks that are integral to the program.

Participation in DB led the majority of children to understand that there were differences between themselves and their partner schools but that this did not in any way diminish their enjoyment of the experience.

Asked if they enjoyed taking part in DB, $93 \%$ of students said yes, with an equal percentage of students on each side of the border. There was a very slight difference between Catholic students' and Protestant students' responses, with $95 \%$ of Catholic students and $89 \%$ of Protestant students claiming they enjoyed the participation. When asked to explain why they enjoyed taking part, the common theme running through individual responses was that children 
enjoyed communicating with other children across the border by sending them messages in forums, working together in wikis, meeting them in videoconferences and meeting them face to face.

DB seemed to open up a curiosity in children. The DB program gave them the opportunity to find out how those on the other side of the border lived. Making new friends was also a recurrent theme. It also gave them an opportunity to use ICT and this use of ICT over a sustained period of time (at least one year) enabled students to maintain contact and build relationships. It was most often a combination of all these things that made DB so enjoyable for students.

For those students who did not participate in $\mathrm{DB}$, there was a marked difference in attitude towards communicating with students in another school, with over $20 \%$ of this cohort responding "no" to the question "Do you like the idea of sending messages to students in another school?," and 15\% stating that they did not know; this compared to $5 \%$ of DB students saying they did not wish to communicate and $8 \%$ saying they were unsure. We interpret this to suggest that there is a fear of the unknown among students who have not been involved but that when students do participate, the experience is positive for the vast majority $(87 \%)$ and this feeling persists at least one year after their involvement.

In this report we have argued that in the current contexts of both post-conflict Northern Ireland and post-Celtic Tiger Republic of Ireland there continues to be a need for school-based programs that can engender positive intercultural understanding among children. In the context of cultural and religious differences and the economic and political turmoil of the time, it would be very difficult to identify any single cause of observed attitudinal differences in school students; however, we believe our findings suggest that the Dissolving Boundaries program does have a positive influence on the development among students of attitudes and behaviours that are culturally aware, open, positive and respectful towards others. In other words, the program nurtures an environment that mirrors the aspirations of the Good Friday/Belfast Agreement signed a decade and a half ago.

\section{ACKNOWLEDGMENT}

The authors acknowledge the insights and comments of Professor Bill Hunter, University of Ontario Institute of Technology.

\section{REFERENCES}

Amichai-Hamburger, Y., \& McKenna, K. Y. A. (2006). The Contact Hypothesis Reconsidered: Interacting via the Internet. Journal of ComputerMediated Communication, 11(3), 825-843. doi:10.1111/j.1083-6101.2006.00037.x

Archick, K. (2013, January 10). Northern Ireland: The Peace Process. Congressional Research Service: Report for Congress, RS21333, 1-17.

Austin, R. (2006). The Role of ICT in bridge-building and social inclusion; theory, policy and practice issues. European Journal of Teacher Education, 29(2), 145-161. doi:10.1080/02619760600617284

Austin, R. (2011). ICT, Enterprise Education and Intercultural Learning. International Journal of Information and Communication Technology Education, 7(4), 60-71. doi:10.4018/jicte.2011100106

Austin, R., Abbott, L., Mulkeen, A., \& Metcalfe, N. (2003). Dissolving boundaries: Crossnational co-operation through technology in education. Curriculum Journal, 14(1), 55-84. doi:10.1080/0958517032000055938

Austin, R., \& Hunter, W. (2013). Online Learning and Community Cohesion. Linking Schools (pp. 1-175). New York: Routledge.

Bekerman, Z., Zembylas, M., \& McGlynn, C. (2009). Working toward the de-essentialization of identity categories in conflict and postconflict societies: Israel, Cyprus, and Northern Ireland. Comparative Education Review, 53(2), 213-234. doi:10.1086/597482

Bonnell, J., Copestake, P., Kerr, D., Passy, R., Reed, C., Salter, R., (2010). Teaching approaches that help to build resilience to extremism among young people (Research Report DFE-RR119) OPM and National Foundation for Educational Research. 
Brown, R. J. (2000). Group Processes: Dynamics within and between groups Oxford. Blackwell.

Connolly, P. (2000). What now for the contact hypothesis? Towards a New Research Agenda. Race, Ethnicity and Education, 3(2), 169-193. doi:10.1080/13613320050074023

Connolly, P., Kelly, B., \& Smith, A. (2009). Ethnic habitus and young children: A case study of Northern Ireland. European Early Childhood Education Research Journal, 17(2), 217-232. doi:10.1080/13502930902951460

Connolly, P., Smith,A., \& Kelly, B. (2002). Too Young to Notice? The Cultural and Political Awareness of 3-6 Year Olds in Northern Ireland, A report commissioned by the Northern Ireland Community Relations Council in Partnership with Channel 4, Belfast.

Cress, U., \& Kimmerle, J. (2008). Asystemic and cognitive view on collaborative knowledge building with wikis. Computer-Supported Collaborative Learning, 3(2), 105-122. doi:10.1007/s11412-007-9035-z

De Burca, A., \& Hayward, K. (2012). The Agreement Generation: Young people's views on the cross-border relationship. Journal of Cross Border Studies in Ireland, 7, 23-36.

Devine, D., Kenny, M., \& Macneela, E. (2008). Naming the 'other': Children's construction and experience of racisms in Irish primary schools. Race, Ethnicity and Education, 11(4), 369-385. doi:10.1080/13613320802478879

Donnelly, C. (2010). Constructing the ethos of tolerance and respect in an integrated school: The role of teachers. British Educational Research Journal, 30(2),263-278. doi:10.1080/0141192042000195254

Donnelly, C., \& Hughes, J. (2006). Contact, culture and context: Evidence from mixed-faith schools in Northern Ireland and Israel. Comparative Education, 42(4), 493-516. doi:10.1080/03050060600988395

Education and Training Inspectorate. (2011). Joint Evaluation Report, Department of Education and Skills Inspectorate - Republic of Ireland - Northern Ireland, Dissolving Boundaries Programme 2010/2011.

Gallagher, T. (2008). Diversity or division? Experiences of education in Northern Ireland: the past cannot be changed but the future can be developed. In D. Schubotz, \& P. Devine (Eds.), Young people in post-conflict Northern Ireland, Lyme Regis: Russell House.
Hasler, B. S., \& Amichai-Hamburger, Y. (2013). Online intergroup contact In Amichai-Hamburger.Y (Ed.), The social net. Human behavior in cyberspace (2nd ed.) 220-252. New York: Oxford University Press.

Hoter, E., Shonfeld, M., \& Ganayem, A. (2009). ICT in the service of multiculturalism. The International Review of Research in Open and Distance Learning, 10(2).

Kampf, R. (2011). Internet, conflict and dialogue: The Israeli case. Israel Affairs, 17(3), 384-400. do i: $10.1080 / 13537121.2011 .584666$

Leavy, A. (2005). When I meet them I talk to them: The challenges of diversity for preservice teacher education. Irish Educational Studies, 24(2-3), 159-177. doi:10.1080/03323310500435422

LeBaron, J., \& McDonough, E. (2009). Research Report for GeSCI Meta-Review of ICT in Education Phase Two. Available online at: http://www.gesci. org/assets/files/Research/meta-researchphase2. pdf (accessed 6 July 2012).

Ligorio, M., \& Van der Meijden, H. (2008). Teacher guidelines for cross-national virtual communities in primary education. Journal of Computer Assisted Learning, 24(1), 11-25. doi:10.1111/j.13652729.2007.00240.x

Livingstone, S. (2012). Critical reflections on the benefits of ICT in education. Oxford Review of Education, 38(1), 9-24. doi:10.1080/03054985.2 011.577938

McCall, C., \& O'Dowd, L. (2008). Hanging flower baskets, blowing in the wind? Third-sector groups, cross-border partnerships, and the EU peace programs in Ireland. Nationalism \& Ethnic Politics, 14(1), 29-54. doi:10.1080/13537110701872576

McGlynn, C. (2009). Negotiating cultural difference in divided societies: An analysis of approaches to integrated education in Northern Ireland. In C. McGlynn, M. Zembylas, Z. Bekerman, \& T. Gallagher (Eds.), Peace education in conflict and post-conflict societies: comparative perspectives (pp.9-25). New York: Palgrave Macmillan. doi:10.1057/9780230620421

Montgomery, A., \& McGlynn, C. (2009). New peace, new teachers: Student teachers' perspectives of diversity and community relations in Northern Ireland. Teaching and Teacher Education, 25(3), 391-399. doi:10.1016/j.tate.2008.11.002 
Muldoon, O., McLaughlin, K., \& Trew, K. (2007). Adolescents' perceptions of national identification and socialization: A grounded analysis British. Journal of Developmental Psychology, 25(4), 579-594. doi:10.1348/026151006X173305

Niens, U., \& Chastenay, M.-H. (2008). Educating for peace? Citizenship education in Quebec and Northern Ireland'. Comparative Education Review, 52(4), 519-540. doi:10.1086/591296

Nolan, P. (2012). The Northern Ireland Peace Monitoring Report. Belfast: Community Relations Council.

O’Dowd, L., \& McCall, C. (2006). The significance of the cross-border dimension for promoting peace and reconciliation. IBIS Working Papers; 55; MFPP Working Papers; 5 Institute for British-Irish Studies University College Dublin.
Pettigrew, T. (1998). Intergroup contact theory. Annual Review of Psychology, 49(1), 65-85. doi:10.1146/ annurev.psych.49.1.65 PMID:15012467

Trew, K. (1989). Evaluating the impact of contact schemes for Catholic and Protestant children. In J. Harbison (Ed.), Growing up in Northern Ireland. Belfast: Stranmillis College.

Waldron, F., \& Pike, S. (2007). What does it mean to be Irish? Children's construction of national identity. Irish Educational Studies, 25(2), 231-251. doi:10.1080/03323310600737586

Xie, K., Miller, N., \& Allison, J. (2013). Toward a social conflict evolution model: Examining the adverse power of conflictual social interaction in online learning. Computers \& Education, 63, 404-415. doi:10.1016/j.compedu.2013.01.003

Angela Rickard, Co-Director of Dissolving Boundaries, is a lecturer in Education at Maynooth University. She has undertaken and written about a number of research initiatives involving partners in Ireland and further afield, in the areas of Intercultural learning, Educational Technology, Development Education, Language Teaching and Teacher Professional Development.

Alma Grace is a qualified teacher of Geography, Science and Maths. She is currently the research and administrative assistant on the Dissolving Boundaries program.

Roger Austin, Co-Director of Dissolving Boundaries, is Professor of Education at the University of Ulster in Northern Ireland. He has published extensively on the role of ICT in teaching and learning with particular reference to its place in citizenship education in schools, teacher education and in higher education. His interests embrace ICT policy implementation in schools nationally and internationally.

Jane Smyth has been the Dissolving Boundaries program manager since it was set up in 2000 and is the coauthor of numerous research reports on its outcomes. She has a background in modern language teaching. 